\title{
First report of white rust caused by Albugo trianthemae on Lampranthus sp. in Italy
}

\author{
Domenico Bertetti $^{1} \cdot$ Giulia Tabone $^{1} \cdot$ Maria Lodovica Gullino ${ }^{1} \cdot$ Angelo Garibaldi $^{1}$
}

Received: 11 November 2021 / Accepted: 22 February 2022 / Published online: 4 March 2022

(c) The Author(s) under exclusive licence to Società Italiana di Patologia Vegetale (S.I.Pa.V.) 2022

Keywords Ornamental plants · Foliar diseases · White rust

Lampranthus sp., Aizoaceae family, is one of several pot flowering plants grown in the Savona province (Liguria region, northern Italy). During April 2021, about 2000 plants of Lampranthus sp. growing in a farm located in Albenga, showed symptoms and signs of a white rust. Several whitish pustules appeared on leaves and calyxes that yellowed and twisted. Finally, the affected plants died. The disease incidence was $90 \%$. All the cultivars were affected but not that with yellow flower. Pustules contained globose to cuboid sporangia measuring 17.3-27.1 × 13.7-23.3 (average: $21.9 \times 18.1) \mu \mathrm{m}$. A suspension of sporangia was obtained from affected leaves and the DNA of the pathogen was extracted. A PCR reaction was performed for the ITS (White et al. 1990) and COX2 (Hudspeth et al. 2000) regions. Two sequences with 162 and 553 base pairs (GenBank accession numbers MZ779025; OM317763 respectively) were obtained. The NCBI blast analysis of both the sequences showed 100\% identity with Albugo trianthemae (FJ234425; AY913800 respectively) whose morphological characteristics are in agreement with those described above. In the pathogenicity test, a sporangial suspension $\left(5 \times 10^{4}\right.$ sporangia/ml) obtained from affected leaves was stored at $5{ }^{\circ} \mathrm{C}$ to favor the zoospore formation and then sprayed on leaves of three healthy plants of Lampranthus sp.. Three control plants were sprayed with sterile water. Plants were covered with plastic bags for 6 days and maintained at $20^{\circ} \mathrm{C}$.
After 15 days, first symptoms of white rust developed on inoculated leaves that, successively, died. Globose to cuboid sporangia observed on artificially inoculated leaves were identical in morphology and size to those described above. No symptoms appeared on control plants. A. trianthemae has been reported on different hosts (Farr and Rossman 2021), including Lampranthus sp.. This is the first report of A. trianthemae on Lampranthus sp. in Italy. A. trianthemae could become a serious threat to Lampranthus in Italy. Further research is needed to verify the potentially resistant cultivars of this host.

\section{References}

Farr DF, Rossman AY (2021) Fungal Databases, U.S. National Fungus Collections, ARS, USDA. https://nt.ars-grin.gov/fungaldatabases/. Accessed 20 Oct 2021

Hudspeth DS, Nadler SA, Hudspeth ME (2000) A COX2 molecular phylogeny of the Peronosporomycetes. Mycologia 92:674-684

White TJ, Bruns T, Lee S, Taylor JW (1990) Amplification and direct sequencing of fungal ribosomal RNA genes for phylogenetics. In: Innis MA, Gelfand DH, Sninsky JJ, White TJ (eds) PCR Protocols: A Guide to Methods and Applications. Academic Press, San Diego, California, USA, pp 315-322

Publisher's Note Springer Nature remains neutral with regard to jurisdictional claims in published maps and institutional affiliations.
Domenico Bertetti

domenico.bertetti@unito.it

1 Centre of Competence AGROINNOVA, University of Torino, Largo Braccini 2, 10095 Grugliasco, Italy 